\title{
Total Carotenoids, Antioxidant and Anticancer Effect of Penaeus monodon Shells Extract
}

\author{
Muammar Fawwaz 1,* ${ }^{\mathbb{D}}$, Mamat Pratama ${ }^{1 \mathbb{D}}$, A Hasrawati $^{1}{ }^{(\mathbb{D}}$, Sukmawati ${ }^{1}{ }^{(\mathbb{D}}$, Harti Widiastuti ${ }^{1}$, \\ Rahmawati $^{1}$ (D), Zainal Abidin ${ }^{1}$ (D)
}

1 Faculty of Pharmacy, Universitas Muslim Indonesia, Makassar 90231, Indonesia

* Correspondence: muammar.fawwaz@umi.ac.id;

Scopus Author ID 56085116100

Received: 9.11.2020; Revised: 5.12.2020; Accepted: 7.12.2020; Published: 10.12.2020

\begin{abstract}
Tiger shrimp (Penaeus monodon) is a species of Crustaceans containing carotenoids in the shell known as powerful antioxidants. This study aims to determine the total amount of carotenoids in the extract of tiger shrimp shells and evaluate the antioxidant and anti-cancer cell proliferation activity by in vitro assay. The extract was obtained by maceration using $n$-hexane. The total amount of carotenoids in the extract was to be determined equivalent to $\beta$-carotene. The UV-Visible spectrophotometer measured the sample solution and standard references at the maximum wavelength of $\beta$-carotene (462 nm). Two different methods performed an evaluation of antioxidant activity; 1,1 diphenyl-2-picryl-hydrazil (DPPH) radical scavenging and $\beta$-carotene bleaching method. Antiproliferative activity was determined toward three different human lung cancer cell lines (H1975, H3255, and H441) by the thiazolyl blue tetrazolium bromide (MTT) assay. The results showed that the total carotenoid total is $5.23 \mathrm{mg} / \mathrm{g}$, equivalent to $\beta$-carotene. The $\mathrm{IC}_{50} \mathrm{DPPH}$ value of extract (110.87 $\mu \mathrm{g} / \mathrm{mL})$ indicating medium potency as an antioxidant compared to that in standard quercetin (6.87 $\mu \mathrm{g} / \mathrm{mL})$. However, the bleaching activity of extract (67\%) was comparable to that in standard quercetin (77\%). The extract revealed extremely potent antiproliferative activity against the H1975 cell line with $\mathrm{IC}_{50} 2.77 \mu \mathrm{g} / \mathrm{mL}$. Thus, it can be concluded that the tiger shrimp shells extract is a good natural resource as either antioxidant or anti-cancer cell proliferation activity toward H1975 cell lines.
\end{abstract}

Keywords: $\beta$-carotene; cancer cell lines; DPPH; MTT; tiger shrimp.

(C) 2020 by the authors. This article is an open-access article distributed under the terms and conditions of the Creative Commons Attribution (CC BY) license (https://creativecommons.org/licenses/by/4.0/).

\section{Introduction}

The Food and Agriculture Organization (FAO), shrimp consumption in several countries is increasing globally. Total shrimp consumption in the USA increased from the previous year to 496,287 tonnes from January - September 2019. Indonesia is one of the largest shrimp exporters to the USA, with a total of more than 240,000 tonnes in 2019 [1]. Generally, shrimp is exported in the frozen form with or without shells, depending on market demand. Thus, the shrimp processing will remain about 50-60\% solid waste as a byproduct [2]. The increase in shrimp exports is in line with the increase in solid waste in the form of shrimp shells; therefore, processing and utilization of waste are needed to reduce environmental pollution.

Previous studies have shown that the shrimp shells waste can be used as a raw material to produce a high-value product [3-5]. It is due to the active compounds, including $18-40 \%$ protein, 35\% minerals, and $14-30 \%$ chitin-chitosan [6-8]. Some studies reported that shrimp shells are a glucosamine $\mathrm{HCl}$ and carotenoid source, especially astaxanthin [9-11]. Carotenoids 
as color pigments in shrimp shells, crab shells, and salmon. These dyes are derived from the food (algae) eaten by this animal [12,13]; because algae can synthesize xanthophylls groups of carotenoids, like loraxanthin, astaxanthin, canthaxanthin, diatoxanthin, diadinoxanthin, and fucoxanthin [13-15]. Several studies have proved that carotenoids contribute not only as antioxidants but also to many cancer diseases [16-18].

Cancer is the most critical health problem because of high mortality and morbidity globally. Some inventions provide by scientists and physicians to inhibit cancer progression. The National Cancer Institute (NCI) reported cancer treatment, including chemotherapy, surgery, radiotherapy, immunotherapy, hormone therapy, stem cell therapy, and precision medicine such as nuclear medicine [19]. However, these treatments remain limited, such as side effects and drug resistance. Besides, cancer cells are known to develop drug resistance due to mutation progression [20-22]. Therefore, a new treatment method should be invented, such as the natural product approach [23]. This study aims to determine the total carotenoid content in the extract of tiger shrimp shells and evaluate its antioxidant activity. The extract will be evaluated the anti-cancer cell proliferation activity through three different human lung cancer cell lines; H1975, H3255, and H441.

\section{Materials and Methods}

\subsection{Chemicals and standard solution.}

The solvents and other chemicals were of analytical grade. 1,1-Diphenyl-2-picrylhydrazyl (DPPH), rociletinib, quercetin, $\beta$-carotene, linoleic acid, Tween 80, 3-(4, 5dimethylthiazolyl-2-yl)-2,5-diphenyl tetrazolium bromide (MTT) were purchased from Sigma Chemicals Co. (St. Louis, MO, USA). Deionized water was obtained through a Millipore-Q50 Ultrapure water system (Sartorius). DMEM/Ham's F-12 and RPMI-1640 medium, penicillinstreptomycin, phosphate-buffered saline (PBS), and trypsin-EDTA $(0.25 \%)$ were obtained from Nacalai Tesque, Inc., (Kyoto, Japan). Fetal bovine serum (FBS) was obtained from Biowest (Nuaillé, France). The stock solution of $\beta$-carotene $(c=1000 \mu \mathrm{g} / \mathrm{mL})$ was prepared by dissolving $10 \mathrm{mg}$ of $\beta$-carotene into $10 \mathrm{~mL}$ chloroform. Stock standard solutions of $\beta$-carotene $(1000 \mu \mathrm{g} / \mathrm{mL})$ were used for preparation of calibration standards at the concentrations $2 ; 3 ; 4$; 5; and $6 \mu \mathrm{g} / \mathrm{mL}$.

\subsection{Sample preparation.}

The sample of tiger shrimp shells (Penaeus monodon) was obtained from industrial waste PT. Bomar Indonesia Makassar. The sample code UW0985002 was collected after the Raw Material Division of Bomar Group Company was identified as a seafood exporter in MakassarIndonesia. The sample was confirmed by the Division of Botany, Pharmacognosy and Phytochemistry Laboratory, Faculty of Pharmacy, Universitas Muslim Indonesia. The sample was washed with water, dried in the sun for about two days, after being dried, and then mashed and sieved to obtain a powder with smaller particle size.

\subsection{Determination of total carotenoids content.}

This experiment was performed in triplicate. The mixture of shell powder $5 \mathrm{~g}$ and $\mathrm{n}$ hexane $50 \mathrm{~mL}$ was placed on the vortex for 30 seconds then placed in the water bath at $50{ }^{\circ} \mathrm{C}$ for 10 minutes. The liquid and the residue were separated using a centrifuge at $3000 \mathrm{rpm}$ for 
five minutes. This procedure was repeated three times, and then the supernatant was concentrated to obtain a thickened extract $[24,25]$. The extract of a sample of $10 \mathrm{mg}$ dissolved in $10 \mathrm{~mL}$ of chloroform to obtain $1000 \mathrm{ppm}$. A $5 \mathrm{~mL}$ sample was then diluted with chloroform in a measuring flask of $10 \mathrm{~mL}$ to acquire $500 \mu \mathrm{g} / \mathrm{mL}$ from the solution. The calibration standards and sample solution were then measured on a UV-Visible spectrophotometer at a maximum wavelength of $462 \mathrm{~nm}$.

\subsection{Determination of antioxidant activity by DPPH assay.}

Antioxidant capacity is determined by scavenging the DPPH radical, as described by Liu et al., which is modified for the present assays. Extract $500 \mu \mathrm{g} / \mathrm{mL}$ were diluted to prepare a concentration of 50,100,150, and $200 \mu \mathrm{g} / \mathrm{mL}$. Every $1 \mathrm{~mL}$ of sample mixed with one $\mathrm{mL}$ of DPPH-solution $(0.4 \mathrm{mM})$ and $2 \mathrm{~mL}$ methanol in a lockable glass envelope, transferred in a disposable polystyrene cuvette, and the UV-Visible spectrum measured after exactly $30 \mathrm{~min}$ of reaction time at the $37^{\circ} \mathrm{C}$. A blank sample was prepared in the same way, but only with $2 \mathrm{~mL}$ methanol and $1 \mathrm{~mL}$ DPPH-solution. Every sample was prepared and measured three times. Due to the photosensitivity of the DPPH, samples are protected from light until analyses [26]. The inhibition of the DPPH radical was calculated with the equation. Inhibition is the ratio between the decrease of the absorbance in the sample and the blank DPPH solution's initial absorbance at $515 \mathrm{~nm}$. The same was done for the quercetin $100 \mu \mathrm{g} / \mathrm{mL}$ diluted to get concentrations $1,2,3$, and $4 \mu \mathrm{g} / \mathrm{mL}$ as a standard reference. The percentages of inhibition of the DPPH radical, as a function of the effect extracted fractions, were calculated using the following equation, where $\mathrm{AcO}_{\mathrm{co}}$ : the absorbance of the control at $\mathrm{t}=0$; $\mathrm{A}_{\mathrm{AT}}$ : the absorbance of the samples at $\mathrm{t}=30 \mathrm{~min}$.

$$
\% \text { Inhibition }=\frac{A_{C O}-A_{A T}}{A_{C O}} \times 100 \%
$$

\subsection{Determination of antioxidant activity by $\beta$-carotene bleaching assay.}

The $\beta$-carotene bleaching method is widely used to measure antioxidant activity in extracts of the natural product. This method is an in vitro test that measures the inhibition of auto-oxidation of linoleic acid to $\beta$-carotene. $\beta$-carotene $(3.0 \mathrm{mg}$ ), linoleic acid $(30 \mathrm{mg})$, and Tween $80(600 \mathrm{mg})$ were dissolved in $5.0 \mathrm{ml}$ of chloroform, respectively. Each solution was added to the Erlenmeyer flask; the chloroform evaporated, then added deionized water (60 $\mathrm{mL})$, stirred until an emulsion formed. $\beta$-carotene-linoleate emulsion $(2.0 \mathrm{~mL})$ was mixed with an extract solution $1000 \mu \mathrm{g} / \mathrm{mL}$ in $n$-hexane $(1.0 \mathrm{~mL})$ in disposable cuvettes, then incubated at $50{ }^{\circ} \mathrm{C}$ in a water bath for $120 \mathrm{~min}$. Absorption at $458 \mathrm{~nm}$ of the sample was measured immediately at $0 \mathrm{~min}$ and every $15 \mathrm{~min}$ to $120 \mathrm{~min}$ with a spectrophotometer [27,28], blank and control using $\beta$-carotene-linoleate emulsion $(4.0 \mathrm{~mL})$ in $n$-hexane $(0.4 \mathrm{~mL})$. All procedures were performed triplicate as applied for the quercetin $100 \mu \mathrm{g} / \mathrm{mL}$ as a standard reference.

$$
\text { Antioxidant activity }(\%)=\left[\left(A_{0}-A_{t}\right) /\left(A_{0}^{o}-A_{t}^{o}\right)\right] \times 100
$$

Where $\mathrm{A} 0$ and $\mathrm{At}$ are corrected absorbance values for test samples measured at zero time and after incubation, respectively, while $\mathrm{A}^{\circ} 0$ and $\mathrm{A}^{\circ}$ thave corrected absorbance values for the control at time zero and at time $\mathrm{t}$ after incubation, respectively [29,30]. 


\subsection{Cell culture.}

Human lung cancer cell lines; H441, H3255, and H1975 were cultured in a medium supplemented with $10 \%$ fetal bovine serum (FBS) and $1 \%$ penicillin-streptomycin. The cells were incubated at $37{ }^{\circ} \mathrm{C}$ in a $\mathrm{CO}_{2}$ incubator in an atmosphere of humidified $5 \% \mathrm{CO}_{2}$ and $95 \%$ air. The cells were maintained by sub-culturing in $25 \mathrm{~cm}^{2}$ tissue culture flasks. Cells growing in the exponential phase were used for cell viability assay [19].

\subsection{Determination of cytotoxicity by MTT assay.}

MTT assay was used to determine the inhibition of cancer cell proliferation by extract of tiger shrimp shells. In brief, cancer cell lines H441, H3255, and H1975 were seeded into 96well plates ( $1 \times 10^{5}$ cells/well in $100 \mu \mathrm{L}$ of media) and allowed to attach for $24 \mathrm{~h}$. The extract was prepared $1000 \mu \mathrm{g} / \mathrm{mL}$ in $1 \%$ DMSO and serially diluted with media to obtain desired concentrations $100,50,10,5,1,0.5,0.1,0.05,0.01,0 \mu \mathrm{g} / \mathrm{mL}$. Cells were treated with serial concentrations of extract and incubated for $48 \mathrm{~h}$. Cells in the control group supplemented only media containing $1 \%$ DMSO. The test compound containing media was removed and washed with $100 \mu \mathrm{L}$ of PBS followed by the addition of $20 \mu \mathrm{L}$ of MTT reagent $(5 \mathrm{mg} / \mathrm{mL}$ MTT in PBS) and incubated for $3 \mathrm{~h}$ at $37^{\circ} \mathrm{C}$. The medium was removed and $100 \mu \mathrm{L}$ DMSO was added. The absorbance measured using a microplate reader at $540 \mathrm{~nm}$, followed by the calculation of percentage viability. Percentage cell viability $=100-[((\mathrm{Ao}-\mathrm{At}) / \mathrm{Ao}) \times 100]$, where Ao $=$ Absorbance of cells treated with 1\% DMSO medium, At $=$ Absorbance of cells treated with extract. $1 \%(\mathrm{v} / \mathrm{v})$ DMSO in the medium was used as a negative control. Each treatment was performed in triplicate. Rociletinib was used as a standard reference. IC50 values were calculated using dose-response inhibition curves in GraphPad Prism (GraphPad Software 8.0, La Jolla, CA, USA).

\subsection{Statistical analysis.}

All of the presented data are the means \pm SD of at least three independent experiments. Statistical analysis was performed by GraphPad Prism 8.0. Differences between groups were analyzed by two-way ANOVA followed by a Benjamini's multiple-comparison test. The level of statistical significance was set to a $p<0.001$.

\section{Results and Discussion}

The maximum extraction of extraction requires that the solvent penetrate the cell and dissolve the target compounds based on the polarity. Many organic solvents can be used depending on the polarity of a compound; in this study, we chose $n$-hexane due to its ability to extract carotenoids in the sample. The extraction method is carried out with vortex and reflux at warm temperatures, thus increasing the extraction's effectiveness while considering the compound's stability. The extraction process is repeated to ensure that no more compounds are left in the sample.

\subsection{Determination of total carotenoids content.}

Quantitative analysis of $\beta$-carotene was carried out by UV-Visible spectrophotometry at a wavelength of $462 \mathrm{~nm}$ as the maximum wavelength of $\beta$-carotene. The concentration series of $2,3,4,5$, and $6 \mu \mathrm{g} / \mathrm{mL}$ references were analyzed on a UV-Visible spectrophotometer at 
maximum wavelength. The obtained absorbance value of $\beta$-carotene can be seen in Table 1 , and from this data, a curve is obtained, as shown in Figure 1. The R2 value is 0.998, correlation coefficient ( $\mathrm{r}$ ) is 0.998 , and $\mathrm{Vx} 0$ is $2.3 \%$ shows good linearity, where the requirements of $\mathrm{r}>$ 0.995 and $\mathrm{Vx} 0<5 \%$ [31]. Linear regression equations obtained $\mathrm{y}=0.106 \mathrm{x}+0.043$ were used to calculate $\beta$-carotene levels in tiger shrimp shells extract samples. The extract was weighed for $0.5 \mathrm{mg} / \mathrm{mL}$ and analyzed in the same wavelength of standard reference, then calculated the level using the equation of a line. The results of the calculation show the levels of $\beta$-carotene of $5.23 \mathrm{mg} / \mathrm{g}$ extract.

Table 1. Total amount of carotenoids equivalent to the $\beta$-carotene level in tiger shrimp shells

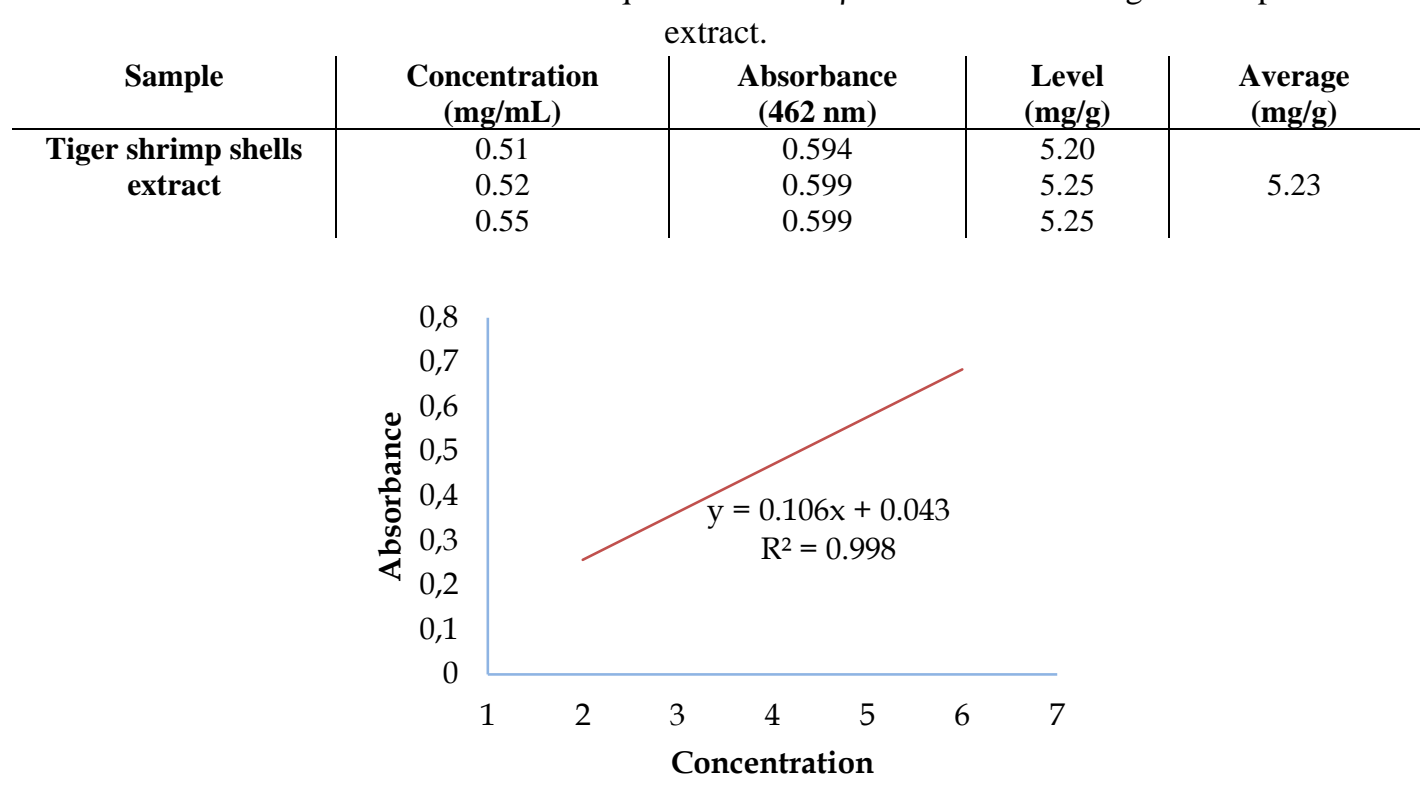

Figure 1. The linear curve of $\beta$-carotene standard references.

The carotenoid content of the extract is closely related to antioxidant activity, so it is necessary to test the antioxidant activity to determine the extract's ability to counteract free radicals. Free radicals are compounds or molecules that contain one or more unpaired electrons in their outer orbitals. The existence of unpaired electrons causes the compound to be very reactive in attacking and binding to the electrons surrounding it to trigger the disease. Free radicals can be formed through normal cell metabolic events, malnutrition, and responses to external influences such as pollution and ultraviolet light. Free radicals play a role in various degenerative diseases because free radicals can damage the macromolecules of cell membranes, DNA, and proteins [32].

\subsection{Determination of antioxidant activity by DPPH assay.}

The antioxidant mechanism of carotenoids is mostly known as radical scavenging; this assay is based on measuring the reducing ability of antioxidants toward DPPH. This method is an in vitro method that is often chosen for antioxidant activity because it is simple, easy, fast, sensitive, and requires a small sample. This method only requires DPPH without adding a substrate because free radicals are available directly to touch the substrate. The ability can be evaluated by electron spin resonance or by measuring the decrease of its absorbance [33]. The results can be observed by changing the solution from purple to yellow. Color changes indicate that DPPH has been reduced by the hydrogen or electron donation process of antioxidant compounds. The absorption decreases gradually as much as the concentration of antioxidant 
compounds. This method uses $\mathrm{IC}_{50}$ as a parameter to determine the concentration of antioxidant compounds that can inhibit $50 \%$ oxidation.

Table 2 showed that the $\mathrm{IC}_{50}$ of the extract is $110.87 \mu \mathrm{g} / \mathrm{mL}$. In comparison, the quercetin is $6.87 \mu \mathrm{g} / \mathrm{mL}$, which confirmed that quercetin's ability is more potent than extract. The antioxidant assay results on extracts showed that the ability to extract in counteracting free radicals was in the medium category. The category as antioxidant based on DPPH assay divided into; powerful, strong, medium, and weak with the $\mathrm{IC}_{50}<50,50-100,100-250,250-500 \mu \mathrm{g} / \mathrm{mL}$, respectively [33].

Table 2. Antioxidant activity of tiger shrimp shells extracts by DPPH method.

\begin{tabular}{|c|c|c|c|c|}
\hline \multirow{11}{*}{ DPPH } & $\begin{array}{c}\text { Concentrations } \\
(\mu \mathrm{g} / \mathrm{mL})\end{array}$ & $\begin{array}{c}\text { Absorbance } \\
(515 \mathrm{~nm})\end{array}$ & $\begin{array}{c}\text { Inhibition } \\
(\%)\end{array}$ & $\begin{array}{c}\mathrm{IC}_{50} \\
(\mu \mathrm{g} / \mathrm{mL})\end{array}$ \\
\hline & & Quercetin & & \\
\hline & 1 & 0.753 & 19.55 & \multirow{4}{*}{6.87} \\
\hline & 2 & 0.704 & 24.59 & \\
\hline & 3 & 0.650 & 30.15 & \\
\hline & 4 & 0.603 & 34.99 & \\
\hline & & Extract & & \\
\hline & 50 & 0.640 & 31.18 & \multirow{4}{*}{110.87} \\
\hline & 100 & 0.483 & 47.35 & \\
\hline & 150 & 0.335 & 62.59 & \\
\hline & 200 & 0.208 & 75.67 & \\
\hline
\end{tabular}

\subsection{Determination of antioxidant activity by $\beta$-carotene bleaching assay.}

Carotenoids are undergoing bleaching when exposed to radicals or oxidize a compound. This process involves breaking a double bond system conjugated either by addition or by cleavage of one of the double bonds. The cleavage can be detected by characterizing the product formed, which is often carbonyl or epoxide. There are at least three possible mechanisms for carotenoid reactions with radical species; (1) electron transfer to radical; (2) radical addition; or (3) allylic hydrogen abstraction [34-36].

In the $\beta$-carotene bleaching method, absorbance measurements were carried out at a wavelength of $458 \mathrm{~nm}$ as the maximum wavelength spectrum of $\beta$-carotene linoleic acid. The absorbance of the control, quercetin, and extract was carried out for 120 minutes with a 15minute interval to inhibit $\beta$-carotene degradation, as shown in Table 3 and Figure 2. Quercetin and extract are considered as substances that can inhibit $\beta$-carotene fading, while the control solution ( $\beta$-carotene-linoleic emulsion) without the addition of antioxidants showed significantly fade away $(P<0.001)$. The absorbance data is used to calculate the percentage of antioxidant activity. According to Hassimotto, the capacity of antioxidants was classified into three levels: strong antioxidants $(>70 \%)$, intermediate $(40-70 \%)$, and weak $(<40 \%)$ [37]. The calculation results showed that the extract is an intermediate antioxidant category with an inhibition of $67 \%$, while the quercetin is a strong antioxidant with a value of $77 \%$.

Table 3. Antioxidant activity of tiger shrimp shells extracts by $\beta$-carotene bleaching method.

\begin{tabular}{c|c|c|c|c}
\multirow{2}{*}{ Incubation time (min) } & \multicolumn{3}{|c}{ Absorbance (458 nm) } \\
\cline { 3 - 5 } & 0 & Control (-) & Quercetin & Extract \\
\hline & 15 & $0.680 \pm 0.06$ & $0.488 \pm 0.02$ & $0.399 \pm 0.01$ \\
B-carotene & 30 & $0.474 \pm 0.06$ & $0.484 \pm 0.02$ & $0.394 \pm 0.01$ \\
bleaching & 45 & $0.431 \pm 0.03$ & $0.471 \pm 0.01$ & $0.379 \pm 0.01$ \\
& 60 & $0.357 \pm 0.03$ & $0.440 \pm 0.01$ & $0.366 \pm 0.01$ \\
& 75 & $0.287 \pm 0.03$ & $0.436 \pm 0.01$ & $0.362 \pm 0.01$ \\
& 90 & $0.259 \pm 0.02$ & $0.415 \pm 0.01$ & $0.336 \pm 0.01$ \\
& 105 & $0.254 \pm 0.02$ & $0.401 \pm 0.01$ & $0.304 \pm 0.02$ \\
& 120 & $0.207 \pm 0.01$ & $0.392 \pm 0.01$ & $0.272 \pm 0.02$ \\
& Activity (\%) & $0.200 \pm 0.01$ & $0.386 \pm 0.01$ & $0.243 \pm 0.02$ \\
\hline
\end{tabular}




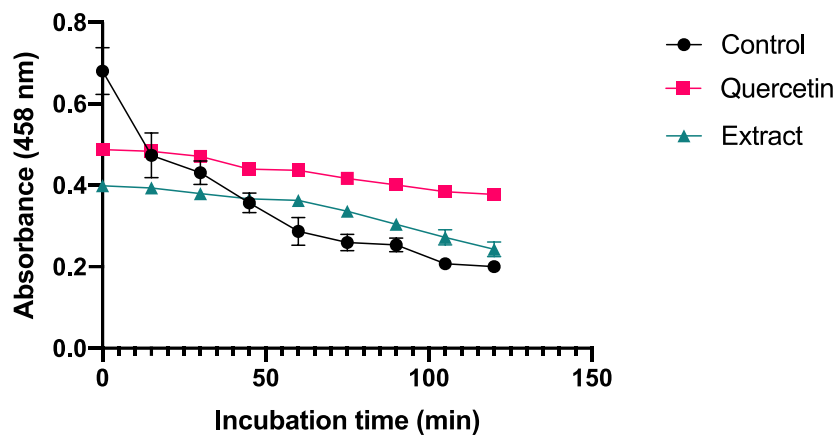

Figure 2. Inhibition activity of quercetin and extract toward $\beta$-carotene bleaching.

\subsection{Determination of cytotoxicity by MTT assay.}

We used three different human lung cancer cell lines in the cell proliferation study based on the mutation status. The cell lines H1975 (T790M mutation), H3255 (L858R mutation), and H441 (wild type) were used due to the expression of the EGFR tyrosine kinase that plays a key role in lung cancer, especially in non-small cell lung cancer (NSCLC) [19]. Nowadays, lung cancer is the deadliest cancer case worldwide, with approximately 1.8 million deaths in 2018 , and the cases will increase due to the resistance to the current therapy. Thus, there is currently a great need to invent a new compound inhibiting cancer progression significantly. Here we present the anti-cancer activity from the tiger shrimp shells extract. The MTT assay in Table 4 showed that the extract has highly potent inhibition activity toward H1975 cells with the IC 50 $2.77 \mu \mathrm{g} / \mathrm{mL}$. A crude extract will be considered to have in vitro anti-cancer activity based on the NCI if the IC50 is less than $20 \mu \mathrm{g} / \mathrm{mL}$ [38].

These data clearly explain that tiger shrimp shell is potential as anti-cancer cell proliferation, particularly to the H1975 lung cancer compared to the reference compound Rociletinib in Figure 3.

Table 4. The $\mathrm{IC}_{50}$ of the extract and reference compound Rociletinib by MTT assay.

\begin{tabular}{l|l|l|l}
\multirow{2}{*}{ Cells } & \multirow{2}{*}{ Mutation status } & \multicolumn{2}{|c}{ IC50 } \\
\cline { 3 - 4 } & & Extract $(\boldsymbol{\mu g} / \mathbf{m L})$ & Rociletinib $(\boldsymbol{\mu M})$ \\
\hline H1975 & L858R/T790M & 2.77 & 0.23 \\
\hline H3255 & L858R & inactive & 0.20 \\
\hline H441 & Wild type & inactive & 0.30 \\
\cline { 2 - 3 } & A & & B
\end{tabular}
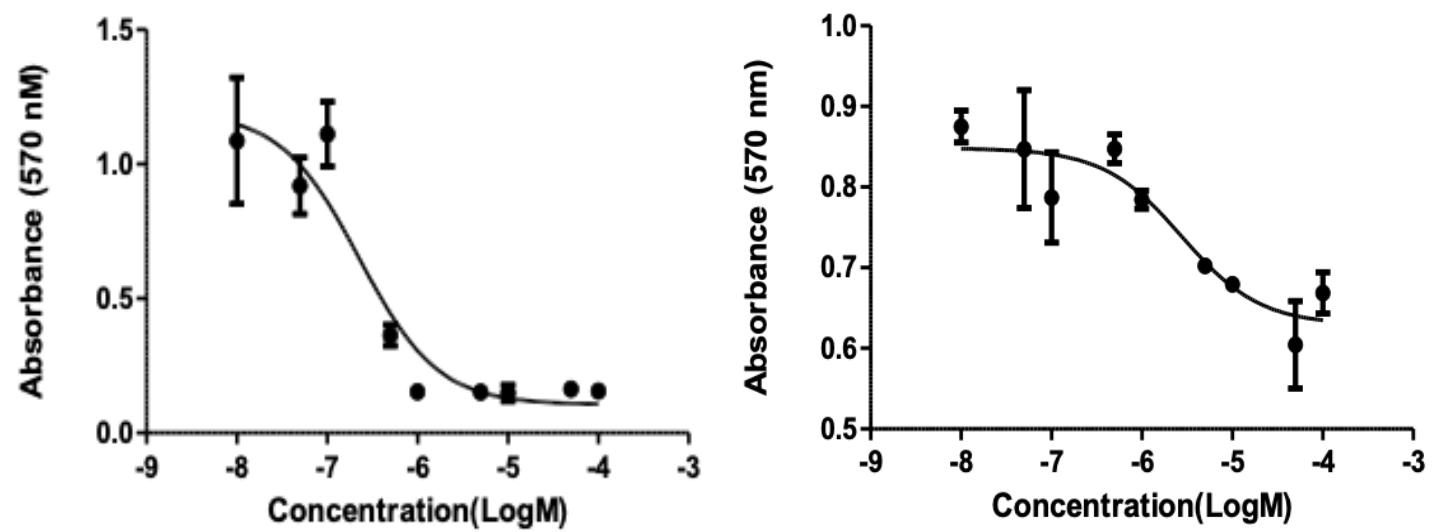

Figure 3. The cell viability was expressed by the $\mathrm{IC}_{50}$ after exposure to Rociletinib (A) and extract (B) by MTT assay. 


\section{Conclusions}

The quantitative analysis showed that tiger shrimp shell extract contains $\beta$-carotene and has a moderate potency as an antioxidant based on DPPH and $\beta$-carotene bleaching assay. The proliferation assays show that the extract has a high potency to inhibit the H1975 cancer cell proliferation in opposite to H3255 and H441 cancer cells.

\section{Funding}

This work was supported in part by LP2S Universitas Muslim Indonesia with the grant number 180506/ist/lp2s/umi.

\section{Acknowledgments}

The authors acknowledge to authorities of the Faculty of Pharmacy and LP2S Universitas Muslim Indonesia for their support and encouragement in carrying this research.

\section{Conflicts of Interest}

The authors declare no conflict of interest. The funders had no role in the study's design; in the collection, analyses, or interpretation of data; in the writing of the manuscript, or in the decision to publish the results.

\section{References}

1. FAO. Globefish Highlights January 2020 Issue, with Jan. - Sep. 2019 Statistics - A quarterly update on world seafood markets; Food and Agriculture Organization of United Nations: Rome, Italy, 2020; 41-46, https://doi.org/10.4060/ca7968en.

2. Nirmal, N.P.; Santivarangkna, C.; Rajput, M.S.; Benjakul, S. Trends in shrimp processing waste utilization: An industrial prospective. Trends in Food Science \& Technology 2020, 103, 20-35, https://doi.org/10.1016/j.tifs.2020.07.001.

3. Deng, J.-J.; Zhang, M.-S.; Li, Z.-W.; Lu, D.-L.; Mao, H.-H.; Zhu, M.-J.; Li, J.-Z.; Luo, X.-C. One-step processing of shrimp shell waste with a chitinase fused to a carbohydrate-binding module. Green Chemistry 2020, 22, 6862-6873, https://doi.org/10.1039/d0gc02611e.

4. Hu, X.; Tian, Z.; Li, X.; Wang, S.; Pei, H.; Sun, H.; Zhang, Z. Green, Simple, and Effective Process for the Comprehensive Utilization of Shrimp Shell Waste. ACS Omega 2020, 5, 19227-19235, https://doi.org/10.1021/acsomega.0c02705.

5. Rengga, W.D.P.; Mubarok, M.A.; Cahyarini, N.S. Utilization of Shrimp Shell Waste as Matrix Controller by Using Ionotropic Gelation Method in Slow Release Fertilizer Based on Environmental Conservation. IOP Conference Series: Earth and Environmental Science 2018, 171, 012036, https://doi.org/10.1088/17551315/171/1/012036.

6. S Suryawanshi, N.; Jujjavarapu, S.E.; Ayothiraman, S. Marine shell industrial wastes-an abundant source of chitin and its derivatives: constituents, pretreatment, fermentation, and pleiotropic applications-a revisit. Int. J. Environ. Sci. Technol. (Tehran) 2019, 16, 3877-3898, https://doi.org/10.1007/s13762-018-02204-3.

7. Okabe, Y.; Inoue, Y.; Kanda, Y.; Katsumata, T. Odor-active compounds contributing to the characteristic aroma of shrimp cooked whole, including shells and viscera. Eur. Food Res. Technol. 2019, 245, 233-241, https://doi.org/10.1007/s00217-018-3156-7.

8. Saleh, A.; Mukhtar, S.; Fawwaz, M.; Pratama, M.; Kosman, R.; Naid, T. Deacetylation degree of chitosan by various bases and its metal adsorption ability related on antioxidant activity. J. Chem. Pharm. Res. 2015, 2015, 265-269.

9. Fawwaz, M.; Vemilia, P.; Mutmainnah, I.; Baits, M. Scylla serrata Forskal as natural source of glucosamine hydrochloride. Journal of Research in Pharmacy 2019, 23, 259-266, https://doi.org/10.12991/jrp.2019.132.

10. Hu, J.; Lu, W.; Lv, M.; Wang, Y.; Ding, R.; Wang, L. Extraction and purification of astaxanthin from shrimp shells and the effects of different treatments on its content. Revista Brasileira de Farmacognosia 2019, 29, 24-29, https://doi.org/10.1016/j.bjp.2018.11.004.

11. Fawwaz, M.; Baits, M.; Saleh, A.; Pratiwi, E. Isolation of glucosamine $\mathrm{HCl}$ from Penaeus monodon. International Food Research Journal 2018, 25, 2173-2176. 
12. Gimeno, M.; Ramírez-Hernández, J.Y.; Mártinez-Ibarra, C.; Pacheco, N.; García-Arrazola, R.; Bárzana, E.; Shirai, K. One-Solvent Extraction of Astaxanthin from Lactic Acid Fermented Shrimp Wastes. J. Agric. Food Chem. 2007, 55, 10345-10350, https://doi.org/10.1021/jf071469h.

13. Koyande, A.K.; Chew, K.W.; Rambabu, K.; Tao, Y.; Chu, D.-T.; Show, P.-L. Microalgae: A potential alternative to health supplementation for humans. Food Science and Human Wellness 2019, 8, 16-24, https://doi.org/10.1016/j.fshw.2019.03.001.

14. Novoveská, L.; Ross, M.E.; Stanley, M.S.; Pradelles, R.; Wasiolek, V.; Sassi, J.-F. Microalgal carotenoids: A review of production, current markets, regulations, and future direction. Mar. Drugs 2019, 17, 640, https://doi.org/10.3390/md17110640.

15. Cezare-Gomes, E.A.; Mejia-da-Silva, L.d.C.; Pérez-Mora, L.S.; Matsudo, M.C.; Ferreira-Camargo, L.S.; Singh, A.K.; de Carvalho, J.C.M. Potential of Microalgae Carotenoids for Industrial Application. Applied Biochemistry and Biotechnology 2019, 188, 602-634, https://doi.org/10.1007/s12010-018-02945-4.

16. Hegazy, G.E.; Abu-Serie, M.M.; Abo-Elela, G.M.; Ghozlan, H.; Sabry, S.A.; Soliman, N.A.; Abdel-Fattah, Y.R. In vitro dual (anti-cancer and antiviral) activity of the carotenoids produced by haloalkaliphilic archaeon Natrialba sp. M6. Scientific Reports 2020, 10, 5986, https://doi.org/10.1038/s41598-020-62663-y.

17. Linnewiel-Hermoni, K.; Khanin, M.; Danilenko, M.; Zango, G.; Amosi, Y.; Levy, J.; Sharoni, Y. The anticancer effects of carotenoids and other phytonutrients resides in their combined activity. Arch Biochem Biophys 2015, 572, 28-35, https://doi.org/10.1016/j.abb.2015.02.018.

18. Young, A.J.; Lowe, G.L. Carotenoids-Antioxidant Properties. Antioxidants (Basel) 2018, 7 , https://doi.org/10.3390/antiox7020028.

19. Fawwaz, M.; Mishiro, K.; Nishii, R.; Sawazaki, I.; Shiba, K.; Kinuya, S.; Ogawa, K. Synthesis and Fundamental Evaluation of Radioiodinated Rociletinib (CO-1686) as a Probe to Lung Cancer with L858R/T790M Mutations of Epidermal Growth Factor Receptor (EGFR). Molecules 2020, 25, https://doi.org/10.3390/molecules25122914.

20. Jin, J.; Wu, X.; Yin, J.; Li, M.; Shen, J.; Li, J.; Zhao, Y.; Zhao, Q.; Wu, J.; Wen, Q. Identification of genetic mutations in cancer: challenge and opportunity in the new era of targeted therapy. Front. Oncol. 2019, 9, 263, https://doi.org/10.3389/fonc.2019.00263.

21. Haider, T.; Pandey, V.; Banjare, N.; Gupta, P.N.; Soni, V. Drug resistance in cancer: mechanisms and tackling strategies. Pharmacol. Rep. 2020, 72, 1125-1151, https://doi.org/10.1007/s43440-020-00138-7.

22. Vasan, N.; Baselga, J.; Hyman, D.M. A view on drug resistance in cancer. Nature 2019, 575, 299-309, https://doi.org/10.1038/s41586-019-1730-1.

23. Ohnishi, S.; Takeda, H. Herbal medicines for the treatment of cancer chemotherapy-induced side effects. Front Pharmacol 2015, 6, 14, https://doi.org/10.3389/fphar.2015.00014.

24. Su, F.; Huang, B.; Liu, J. The carotenoids of shrimps (Decapoda: Caridea and Dendrobranchiata) cultured in China. J. Crust. Biol. 2018, 38, 523-530, https://doi.org/10.1093/jcbiol/ruy049.

25. Khanafari, A.; Saberi, A.; Azar, M.; Vosooghi, G.; Jamili, S.; Sabbaghzadeh, B. Extraction of astaxanthin esters from shrimp waste by chemical and microbial methods. Iranian Journal of Environmental Health Science \& Engineering 2007, 4.

26. Liu, D.; Shi, J.; Colina Ibarra, A.; Kakuda, Y.; Jun Xue, S. The scavenging capacity and synergistic effects of lycopene, vitamin E, vitamin $\mathrm{C}$, and $\beta$-carotene mixtures on the DPPH free radical. LWT - Food Science and Technology 2008, 41, 1344-1349, https://doi.org/10.1016/j.lwt.2007.08.001.

27. McNulty, H.; Jacob, R.F.; Mason, R.P. Biologic Activity of Carotenoids Related to Distinct Membrane Physicochemical Interactions. The American Journal of Cardiology 2008, 101, S20-S29, https://doi.org/10.1016/j.amjcard.2008.02.004.

28. Krinsky, N.I.; Johnson, E.J. Carotenoid actions and their relation to health and disease. Mol. Aspects Med. 2005, 26, 459-516, https://doi.org/10.1016/j.mam.2005.10.001.

29. Palozza, P.; Barone, E.; Mancuso, C.; Picci, N. The protective role of carotenoids against 7-keto-cholesterol formation in solution. Mol. Cell. Biochem. 2007, 309, 61, https://doi.org/10.1007/s11010-007-9643-y.

30. Kulisic, T.; Radonic, A.; Katalinic, V.; Milos, M. Use of different methods for testing antioxidative activity of oregano essential oil. Food Chem. 2004, 85, 633-640, https://doi.org/10.1016/j.foodchem.2003.07.024.

31. Riccioni, G. Carotenoids and cardiovascular disease. Current Atherosclerosis Reports 2009, 11, 434-439, https://doi.org/10.1007/s11883-009-0065-z.

32. Kikuzaki, H.; Hisamoto, M.; Hirose, K.; Akiyama, K.; Taniguchi, H. Antioxidant Properties of Ferulic Acid and Its Related Compounds. J. Agric. Food Chem. 2002, 50, 2161-2168, https://doi.org/10.1021/jf011348w.

33. Kato, S.; Aoshima, H.; Saitoh, Y.; Miwa, N. Highly hydroxylated or $\gamma$-cyclodextrin-bicapped water-soluble derivative of fullerene: The antioxidant ability assessed by electron spin resonance method and $\beta$-carotene bleaching assay. Bioorg. Med. Chem. Lett. 2009, 19, 5293-5296, https://doi.org/10.1016/j.bmcl.2009.07.149.

34. Han, R.M.; Zhang, J.P.; Skibsted, L.H. Reaction dynamics of flavonoids and carotenoids as antioxidants. Molecules 2012, 17, 2140-2160, https://doi.org/10.3390/molecules17022140.

35. Mordi, R.C.; Ademosun, O.T.; Ajanaku, C.O.; Olanrewaju, I.O.; Walton, J.C. Free Radical Mediated Oxidative Degradation of Carotenes and Xanthophylls. Molecules 2020, 25, https://doi.org/10.3390/molecules25051038. 
36. Edge, R.; Truscott, T.G. Singlet Oxygen and Free Radical Reactions of Retinoids and Carotenoids-A Review. Antioxidants (Basel) 2018, 7, https://doi.org/10.3390/antiox7010005.

37. Hassimotto, N.M.A.; Genovese, M.I.; Lajolo, F.M. Antioxidant Activity of Dietary Fruits, Vegetables, and Commercial Frozen Fruit Pulps. J. Agric. Food Chem. 2005, 53, 2928-2935, https://doi.org/10.1021/jf047894h.

38. Pezzuto, J.M. Natural Compounds in Cancer Therapy. John Boik, Oregon Medical Press, Princeton, MN, 2001, \$32.00 (ISBN 0-9648280-1-4). Pharm. Biol. 2002, 40, 79-79, https://doi.org/10.1076/phbi.40.1.79.5858. 